\title{
Piotr Millati: Czy Bruno Schulz był pisarzem?
}

Skąd w ogóle takie pytanie? Odpowiedź wydaje się przecież prosta i banalna. Wystarczy sięgnąć po jakikolwiek szanujący się leksykon pisarzy XX wieku. Nie mieli też w tej sprawie żadnych wątpliwości współcześni Schulzowi krytycy i czytelnicy. Tym bardziej nie przyjdzie ono do głowy tym, którzy dziś zagłębiają się w labirynty Sklepów cynamonowych czy Sanatorium pod Klepsydra.

A jednak, choć to pytanie można uznać za niedorzeczne, warto je

niedorzeczne pytanie

kto jest pisarzem? zadać. Nie dla pustej i wątpliwej prowokacji, ale by uświadomić sobie, że jeśli Schulz faktycznie był pisarzem, to był nim w sposób zupełnie inny niż większość tych, których określamy tym słowem. Jeśli postawić go choćby obok takich pisarzy jak Zofia Nałkowska, Stanisław Ignacy Witkiewicz czy Witold Gombrowicz, którzy w pewnym momencie życia należeli do jego najbliższego artystycznego otoczenia, to pod wieloma względami więcej go od nich dzieli, niż z nimi łączy.

Punktem wspólnym jest oczywiście fakt, że Schulz napisał teksty, które na trwałe weszły do historii światowej literatury. Ale czy uczyniło go to automatycznie takim pisarzem, jak tu wymienieni?

Pisarzem jest ktoś, kto pisze książki - to byłaby chyba najprostsza, zdroworozsądkowa definicja pisarza. Kiedy będę się posługiwał tym słowem, będę tu miał na myśli właśnie taki, najbardziej typowy przypadek bycia pisarzem, gdyż stanowi on najbardziej czytelną opozycję wobec osobliwej pisarskiej egzystencji Schulza.

Z tej przyczyny to, co za chwilę powiem, zadzwoni wam w uszach banałem, zazgrzyta w zębach pretensjonalnością, ale elementarne fakty czasem bywają banalne i pretensjonalne, więc pozwolę sobie na wypowiedzenie tych kilku wyświechtanych „spostrzeżeń”.

Większość pisarzy to ludzie, którzy nie potrafią żyć bez pisania. Pisanie stanowi dla nich nieodparty wewnętrzny przymus, utrzymujący swą moc przez większą część ich życia. Choć sam proces tworzenia zazwyczaj wymaga wysiłku, to pisanie jest dla pisarza stanem tak naturalnym jak oddychanie. Można powiedzieć, że to niemal fizjologiczna czynność jego organizmu. Całe istnienie pisarza koncentruje się wokół tej jednej najważniejszej dla niego aktywności, a reszta życia zostaje jej 
podporządkowana z zimną bezwzględnością, nierzadko kosztem najbliższych osób. Tego rodzaju ludzie mają poczucie, że urodzili się, by pisać, i tylko pisanie nadaje właściwy sens ich życiu. Jeśli pisarz wykonuje jakiś inny zawód, to tylko po to, aby zdobyć środki niezbędne do tego, by żyć, a więc pisać. Pisane przez niego książki bywają raz lepsze, raz gorsze, ale przychodzą na świat z rozsądną regularnością. Poród może być długi, trudny i bolesny, kiedy jednak do niego już dojdzie, po jakimś czasie pojawia się kolejny pomysł na książkę, żądając wydania go na świat.

Schulz napisał bardzo mało, zaczął pisać dość późno i okres, w którym rzeczywiście był pisarzem, trwał stosunkowo krótko. Można powiedzieć, że Schulzowi pisanie opowiadań bardziej się przydarzyło, niż stanowiło trwałą predyspozycję jego artystycznej egzystencji. Było jak krótkotrwały, lecz oślepiający rozbłysk, potężne wyładowanie atmosferyczne, które chwilę po swym zaistnieniu wytraca całą energię.

Z perspektywy swoich czytelników Schulz od razu urodził arcydzieło, które było jednocześnie jego debiutem ${ }^{1}$. Nie poprzedzały go żadne juwenilia, żadne nieudane próby pisarskie, które ujrzałyby światło dzienne, żadne pierwsze, publikowane $\mathrm{w}$ drugorzędnych czasopismach jeszcze nieopierzone teksty, których „popełnienie” z reguły jest niezbędnym etapem na drodze niemal każdego pisarza do osiągnięcia artystycznej dojrzałości².

Należał do osobliwej rodziny pisarzy będących autorami tylko jednej, ale za to genialnej książki³. Wśród jej członków można wymienić Giuseppe Tomasiego di Lampedusę z jego Gepardem, Ralpha Elissona z Niewidzialnym człowiekiem czy Nelle Harper Lee z powieścią Zabić drozda.

Aby osiągnąć to, na co inni pisarze wytrwale pracują całe życie, potrzeba mu było zaledwie dwóch skromnych objętościowo tomów opowiadań, choć w zasadzie wystarczyłby jeden z nich. Gdyby Schulz wydał tylko Sklepy cynamonowe albo tylko Sanatorium pod Klepsydra, jego pozycja w świecie literackim niewiele by na tym ucierpiała. Również gdyby udało mu się napisać legendarnego Mesjasza, nie uczyniłoby go to w naszych oczach pisarzem większym, niż jest teraz.

1 Wcześniej zwracał na to uwagę choćby Jerzy Jarzębski w: J. Jarzębski, Schulz, Wrocław 1999, s. 6.

2 Za tego rodzaju tekst można by uznać opublikowaną przez Schulza na początku 1922 roku w dwutygodniku borysławskich nafciarzy Undulę, którą ostatnio odnalazła we Lwowie Łesia Chomycz. Choć jest to utwór nie tak wybitny jak te, który znalazły się w Sklepach cynamonowych, to bez wątpienia literacko udany.

3 Sklepy cynamonowe oraz Sanatorium pod Klepsydra w zasadzie można traktować jako jeden rozbity na dwa tomy zbiór opowiadań. Większość tekstów, która znalazła się w Sanatorium, została napisana jeszcze przed wydaniem Sklepów. 
Wyobraźmy sobie teraz Nałkowską jako autorkę tylko Kobiet albo Witkacego, który napisałby 622 upadki Bunga, a poza tym nic już więcej, lub Gombrowicza, gdyby zakończył swą przygodę z pisaniem na Pamiętniku $z$ okresu dojrzewania. $\mathrm{O}$ żadnym $\mathrm{z}$ nich nie mówiono i nie pisano by dziś w stopniu nawet zbliżonym do tego, jak się dziś mówi i pisze o Schulzu.

\section{2}

Większość jego opowiadań została napisana w drugiej połowie lat dwupisarz listów dziestych i na początku lat trzydziestych. Wcześniej jego potrzeba pisania prozy o charakterze artystycznym w przeważającej mierze spełniała się w intensywnie prowadzonej korespondencji : „Wyżywałem się kiedyś w pisaniu listów, była to wówczas jedyna moja twórczość" - powie w liście do Andrzeja Pleśniewicza 5 .

Jak wiadomo, spod jego ręki wyszło tysiące listów, z czego ocalała tylko niewielka cząstka. Była to twórczość, którą Schulz uprawiał przez całe życie. W przeciwieństwie do właściwego pisarstwa w bardzo niewielkim stopniu podlegająca jego chwiejnym stanom emocjonalnym. Nie zdołały trwale jej zablokować również żadne niesprzyjające okoliczności obiektywne, które z taką łatwością wytrącały Schulzowi pióro, gdy rzecz dotyczyła pracy nad opowiadaniami. Jego korespondencja z Anną Płockier była nieprzerwanie prowadzona zarówno w okresie sowieckiej, jak i hitlerowskiej okupacji, gdy każdy dzień niósł ze sobą groźbę gwałtownej i brutalnej śmierci.

Tak więc jego zdolność pisania z reguły nie zacinała się, jeśli miał po drugiej stronie znanego sobie odbiorcę i życzliwego czytelnika. Uwodził

uwodzenie czytelnika go i oczarowywał poprzez słowa wypowiadane jakby ściszonym głosem, układające się w hipnotyzujące frazy, przypominające jakąś magiczną inkantację. W tej wyjątkowej aurze wzajemnej bliskości oraz sugerowanego głębokiego porozumienia, jak w sprzyjającym klimacie, dojrzewały zdania, obrazy, pomysły, które później były wykorzystywane jako materiał do opowiadań.

Tego rodzaju pisanie nie było więc celem samym w sobie. Było budowaniem i pogłębianiem wyjątkowej, intymnej relacji z konkretnym człowiekiem. Tekst stawał się niezbędnym narzędziem do jej umacniania.

4 Narzucona przez Jerzego Ficowskiego teza, że cała twórczość Schulza wywodzi się z jego listów, obecnie ustępuje miejsca przekonaniu, że równolegle do korespondencji powstawały też teksty będące prozą literacką. Ficowski w późniejszych latach również łagodził kategoryczność swego przekonania. Zob. nota edytorska do: B. Schulz, Dzieła zebrane, t. 2: Sklepy cynamonowe, wstęp i oprac. J. Jarzębski, dodatek krytyczny S. Rosiek, oprac. językowe M. Ogonowska, Gdańsk 2018 , s. 151.

5 B. Schulz, Dzieła zebrane, t. 5: Księga listów, zebrał i przygotował do druku J. Ficowski, uzupełnił S. Danecki, Gdańsk 2012, s. 120. 
Z drugiej jednak strony Schulz często tracił z oczu odbiorcę swych listów, spychał go na daleki plan, umieszczając go w biernej roli pozbawionego własnego głosu czytelnika. Ich treść często odklejała się od osoby interlokutora, stając się niemal autonomicznym utworem literackim.

Pierwszym znanym nam tego przykładem była w całości zaginiona korespondencja z Emanuelem Pilplem - wieloletnim drohobyckim przyjacielem i wielbicielem twórczości Schulza. Pilpel zachwycony listami od Schulza czytał je na początku lat dwudziestych młodziutkiej wówczas Reginie Silberner, prorokując z uniesionym uroczyście palcem: „zapamiętaj sobie, co ci teraz powiem, Bruno będzie jeszcze wielkim pisarzem"6.

Współobecność tych dwóch elementów - realnego odbiorcy i tekstu literackiego - była niemal warunkiem sine qua non jego aktywności pisarskiej. Ich rozdzielenie, a więc wyjście poza korespondencję i pisanie dla samego pisania, z myślą o abstrakcyjnym czytelniku, można by w zasadzie uznać za krótkotrwały epizod oraz ilościowy margines na tle tego, co stanowiło najczęstszą formę pisarskiej ekspresji Schulza.

\section{3}

Schulz w młodości raczej nie myślał o tym, by zostać pisarzem. Nie znajdziemy żadnych świadectw, które mówiłyby o tym, że swe artystyczne spełnienie wiązałby $z$ literaturą. Żadnych, tak charakterystycznych dla pisarzy in spe marzeń, aby celem życia uczynić pisanie wielkich powieści. Żadnych rojeń o literackiej sławie. Żadnego „terminowania” u podziwianego pisarza, czego wynikiem bywają słabe literacko teksty, naznaczone piętnem nieudolnego naśladownictwa.

Pisarskie (ale też artystyczne) powołanie zazwyczaj rodzi się wcześnie i kiedy stanie się już uświadomione i przyjęte, człowiek z determinacją dąży do jego urzeczywistnienia. Jak choćby Hermann Hesse, który już od trzynastego roku życia wiedział, że będzie poetą albo nikim.

Od najmłodszych lat szkolnych ulubionymi przedmiotami Schulza były rysunki oraz język polski. Jego talent literacki zabłysnął na forum publicznym po raz pierwszy już w jednej z pierwszych klas gimnazjum, kiedy to napisał długie opowiadanie o koniu. Poruszony nim polonista pokazał je dyrektorowi, a ten zachował je dla siebie jako szczególną osobliwość. Ten akt dyrektorskiego uznania dla niepozornego ucznia był w szkole szeroko komentowany ${ }^{8}$.

6 R. Silberner, Strzępy wspomnień. Przyczynek do biografii zewnętrznej Brunona Schulza, Londyn 1984, s. 12.

7 J. Ficowski, Regiony wielkiej herezji i okolice. Bruno Schulz i jego mitologia, Sejny 2002, s. 20.

8 Pisał o tym Michał Chajes - szkolny przyjaciel Schulza - w liście do Jerzego Ficowskiego. Zob. J. Kandziora, Poeta w labiryncie historii. Studia o pisarskich rolach Jerzego Ficowskiego, Gdańsk 2016, s. 221. 
chciał być artystą

„ślub ze sztuką"

Ale Schulz swoje artystyczne spełnienie widział w zupełnie innej dziedzinie. Jak wszyscy wiemy, jego prawdziwą pasją już od najwcześniejszego dzieciństwa był rysunek: „Jeszcze nie umiałem mówić, gdy pokrywałem już wszystkie papiery i brzegi gazet gryzmołami, które wzbudzały uwagę otoczenia..." - napisze w często cytowanym quasi-liście do Witkacego. W opowiadaniu Genialna epoka możemy znaleźć wspaniały literacki obraz początków tej jego niewątpliwie największej i najtrwalszej artystycznej namiętności.

W szkole był dobrze znany ze swoich rysunków, które już wówczas charakteryzowało obsesyjne krążenie wokół tych samych, niepokojących motywów ${ }^{10}$. Przełomowym zdarzeniem, które miało obudzić w nim pragnienie, by zostać artystą plastykiem, było zetknięcie się czternastoletniego Schulza z secesyjnymi ilustracjami Ephraima Mosesa Liliena do książki Lieder des Ghetto: „Dokonał się wówczas we mnie rodzaj przełomu wewnętrznego. Lilien zapłodnił potężnie mój świat wewnętrzny, co się objawiło wczesną, młodzieńczą, nieudolną twórczością. [...] Lilien to była pierwsza wiosna mojej wrażliwości, mój ślub mistyczny ze sztuką [...]"11 - pisał wiele lat po tym zdarzeniu w eseju poświęconym artyście urodzonemu podobnie jak on w Drohobyczu.

Nic nam nie wiadomo, aby Schulz kiedykolwiek rozważał studiowanie literatury, będącej najbardziej oczywistym wyborem tych, którzy myślą o pisaniu. Chciał za to studiować malarstwo. Ostatecznie powstrzymała go przed tym krokiem trzeźwa i asekurancka rada starszego brata, aby wybrał coś bardziej praktycznego. Zapewne musiała ona paść na podatny grunt jego niewiary we własne siły, gdyż ostatecznie znalazł się na wydziale budownictwa Politechniki Lwowskiej, którego nigdy jednak nie ukończył. Później, w Wiedniu, gdzie ucieknie z częścią rodziny przed pustoszącą Galicję wojną, na krótki czas wznowi te studia, ale bez większego przekonania. Przyczynę ich ostatecznego porzucenia wyjaśniał $\mathrm{w}$ pisanym do ministerstwa podaniu o zgodę na nauczanie rysunku w drohobyckim gimnazjum: „[w Wiedniu] pod wpływem dzieł starej sztuki coraz silniej budzący się pociąg do twórczości malarskiej skłonił mnie do przerwania studiów architektury i poświęcenia się zawodowi malarskiemu"12. To właśnie wówczas nabrał ostatecznego przekonania, że malarstwo jest jedyną dziedziną, z którą pragnąłby związać swą przyszłość ${ }^{13}$.

9 B. Schulz, Księga listów, s. 105.

10 J. Ficowski, op. cit., s. 24.

11 B. Schulz, Dzieła zebrane, t. 7: Szkice krytyczne, koncepcja edytorska W. Bolecki, komentarze i przypisy M. Wójcik, oprac. językowe P. Sitkiewicz, Gdańsk 2017, s. 128.

12 B. Schulz, Księga listów, s. 227.

13 J. Ficowski, op. cit., s. 27. 
Na początku lat dwudziestych Schulz rysuje i maluje naprawdę dużo, jednocześnie intensywnie pracując nad doskonaleniem swego warsztatu. Powstaje wówczas najważniejszy cykl jego grafik - Xięga bałwochwalcza. Udaje mu się tu i ówdzie wystawiać swe prace, od czasu do czasu coś sprzedać, ale to wszystko nie przekłada się na sukces finansowy, który pozwoliłby mu na utrzymanie się z takiego zajęcia. Stąd chwilę później smutna konieczność szukania zatrudnienia w szkole. Zanim to jednak nastąpi, Schulz podejmie ostatnią już próbę, by urzeczywistnić swoje pragnienie, by na trwałe związać swe życie z malarstwem - będzie usiłował dostać się do wiedeńskiej Akademii Sztuk Pięknych. W kwietniu 1923 roku stanął przed dziesięcioosobową komisją egzaminacyjną tej uczelni. Nie został jednak przyjęty. Zapewne nie z powodu braku umiejętności, ale - jak podejrzewa Joanna Sass, która opisała ten epizod ${ }^{\mathbf{1 4}}$ ponieważ był już zbyt dobrze ukształtowanym artystą, więc mało podatnym na wpływ akademickiej edukacji15.

W przeciwieństwie do pisania, plastyką będzie się interesować aż do końca. Od dawna nie będzie już aktywnie zajmował się literaturą, ale ambicja, by rozwijać się w dziedzinie malarstwa, pozostanie w nim nadal żywa. Jej ostatni ślad znajdziemy w liście do malarki Anny Płockier, pisanym dokładnie na rok przed jego śmiercią w okupowanym przez nazistów Drohobyczu: „Czy Pani uważałaby za rzecz beznadziejną wziąć mnie w swoją naukę jako adepta malarstwa? Przeprowadzić ze mną, może przy pomocy Marka, kurs malarstwa oczyszczonego od akademickości? Ja w zamian podzieliłbym się z Panią moim doświadczeniem pisarskim"16. Nigdy jednak do tego nie doszło. Jego adresatka została zamordowana wraz z Markiem Zwillichem kilka dni później przez ukraińską milicję.

\section{4}

Każdy wielki pisarz jest najpierw wielkim czytelnikiem. Wybitna literatura zawsze powstaje z uprzedniego czytania wybitnej literatury. Schulz zawsze czytał bardzo dużo, korzystając $\mathrm{z}$ udostępnianych mu za darmo zasobów drohobyckiej księgarni prowadzonej przez ojca jego bliskiego przyjaciela - wspomnianego już tu Emanuela Pilpla. Drugim ważnym źródłem lektur był bogaty księgozbiór, jaki miał u siebie $\mathrm{w}$ domu inny jeszcze drohobycki przyjaciel - Stanisław Weingarten. Znajdowały się w nim książki z przeróżnych dziedzin - od nauk przyrodniczych, 
socjologicznych, historycznych i ekonomicznych po filozofię i poezję. Jerzy Ficowski chciałby w wieloletnim związku Schulza ze sklepowym księgozbiorem Pilplów widzieć bodziec, dzięki któremu „dojrzewał w nim pisarz" i „ujawnił się grafik" ${ }^{17}$. Niewykluczone, choć literatura piękna nie była szczególnie uprzywilejowanym gatunkiem wśród tych lektur. Niewiele wiemy na temat ważnych w tym okresie dla Schulza pisarzy uprawiających tak zwaną literaturę piękną. Jedyne nazwisko wciąż wymieniane przez niego z niemal bałwochwalczą czcią i często powracające w korespondencji to Rilke, a więc przede wszystkim poeta, a dopiero na dalszym planie prozaik. Później dołączą jeszcze do niego Tomasz Mann oraz Franz Kafka.

Jerzy Ficowski początek poważnego zainteresowania Schulza pisaniem łączy z przyjaźnią z Władysławem Riffem- poznanym na początku lat dwudziestych młodszym od niego niemal o dziesięć lat, świetnie zapowiadającym się prozaikiem. To on miał go zainspirować około roku 1925 do podjęcia samodzielnych prób literackich ${ }^{\mathbf{1 8}}$. Według Ficowskiego powstały wówczas takie opowiadania jak: Noc lipcowa, Druga jesień, Edzio, Emeryt, Samotność, Dodo oraz najprawdopodobniej Sanatorium pod Klepsydrą, które wiele lat później będą stanowiły trzon drugiego tomu prozy Schulza ${ }^{19}$. Poprzedzała je intensywnie prowadzona z Riffem korespondencja. Dla obu stron szybko stała się ona pretekstem do uprawiania w jej ramach twórczości czysto literackiej.

Jednak najnowsze odkrycie ukraińskiej badaczki przesuwa moment rzeczywistej inicjacji literackiej Schulza na styczeń 1922 roku, kiedy opublikował w czasopiśmie „Świt” zupełnie dotąd nam nieznane opowiadanie odkrycie Undula, podpisując się pseudonimem Marceli Weron. Łesia Chomycz, bo o niej tu mowa, datuje powstanie Unduli na wiosnę 1920 lub 1921 roku i wyraża przypuszczenie, że mógł być to tekst pomyślany przez Schulza jako literacki komentarz do jego grafik ${ }^{20}$.

Trudno powiedzieć, czy podważa to rolę Riffa w rozbudzeniu ambicji Schulza do samodzielnego pisania - nadal nie wiemy, kiedy dokładnie się poznali. Tak czy inaczej, Riff stał się dla niego bardzo charakterystyczną figurą, kimś, kogo zawsze poszukiwał - bliskim powiernikiem jego myśli oraz towarzyszem dalekich wypraw wyobraźni. Miał być też niezbędnym katalizatorem jego własnej twórczości literackiej, rzekomo po części inspirowanej listami przyjaciela. Riff zmarł na gruźlicę w 1927

17 J. Ficowski, op. cit., s. 47.

18 Ibidem, s. 56-58.

19 Ibidem, s. 58.

20 Ł. Chomycz, Wokół wystawy w Borysławiu. O dwóch debiutach Brunona Schulza, "Schulz/Forum” 14, 2019. 
roku. Wszystkie jego utwory wraz z listami od Schulza zostały spalone przez służby sanitarne, chcące w ten sposób zlikwidować ognisko choroby. Nigdy więc się nie dowiemy, na ile Schulz był jego literackim dłużnikiem, jak to sugeruje Ficowski, który na dowód zależności przytacza zapamiętane przez Adama Ważyka fragmenty listów Riffa, bardzo zbliżone do prozy Schulza ${ }^{21}$. Nie przypisywałbym jednak temu podobieństwu, mającemu swe świadectwo jedynie w pamięci Ważyka, zbyt wielkiej wagi. Świat, z jakim spotykamy się w dziele artysty z Drohobycza, jest tak osobny i niepowtarzalny, że trudno sobie wyobrazić, aby stał się przedmiotem czyjejkolwiek imitacji, nie zamieniając się automatycznie w swoją karykaturę. Przykładem niech będzie bezwstydnie plagiatowe wobec Schulza i artystycznie poronione pisarstwo Kazimierza Truchanowskiego.

Niemal zaraz po śmierci Riffa jego miejsce jako adresata listów Schulza zajmie poznana w Zakopanem siedemnastoletnia Stefania Juer, późniejsza malarka, która będzie znana pod nazwiskiem Dretler-Flin. Napisał ich do niej setki. Były to kilkustronicowe listy-opowiadania, wysyłane w latach 1927-1932 regularnie dwa, trzy razy w tygodniu. Jak większość listów Schulza, również te zaginęły podczas wojny ${ }^{22}$.

W roku 1930 Schulz poznał za pośrednictwem Witkacego żydowską pisarkę Deborę Vogel. Jerzy Ficowski, opierając się na słowach Schulza, uznał, że to z korespondencji z Deborą Vogel ostatecznie narodziły się Sklepy cynamonowe ${ }^{23}$. Przeczyłoby temu jednak świadectwo Zofii Nałkowskiej, która w swym Dzienniku zapisała, że gdy Schulz zjawił się u niej na Wielkanoc 1933 roku, książka była gotowa do druku od trzech lat - a więc jeszcze zanim po raz pierwszy spotkał się on $\mathrm{z}$ autorką Tog figurn $^{\mathbf{2 4}}$. Podważa to również podawany przez Ficowskiego fakt, że kiedy w lipcu 1932 roku Schulz poprosił o lekturę swych opowiadań Stefana Szumana - wybitnego psychologa, którego wykładów słuchał w Żywcu były one już od dwóch lat gotowe do druku ${ }^{25}$.

Tak czy inaczej, Sklepy cynamonowe powstały relatywnie szybko. Podobna erupcja literackiej kreatywności nigdy już się Schulzowi nie przydarzy. W przyszłości będzie wielokrotnie usiłował powrócić do tego cudownego stanu ducha i umysłu, w którym wytwarzał jeden za drugim, niczym w alchemicznej retorcie, tak wspaniałe literacko utwory jak

21 Ibidem, s. 57.

22 B. Schulz, Sklepy cynamonowe, s. 149.

23 "Z moich listów powstały stopniowo Sklepy cynamonowe" - pisał w liście do Romany Halpern. Nie wspomina jednak, że chodziło tylko o listy do Debory Vogel. Idem, Księga listów, s. 142.

24 Idem, Sklepy cynamonowe, s. 152.

25 J. Ficowski, op. cit., s. 204. 
Sierpień czy Ptaki. Jednak, poza nielicznymi wyjątkami, już mu się to więcej nie uda. Jak pamiętamy, wydane w 1937 roku Sanatorium pod Klepsydra będzie w dużej mierze aktem literackiej kapitulacji. Opowiadania $\mathrm{z}$ tego tomu to $\mathrm{w}$ przeważającej części teksty powstałe $\mathrm{w}$ dawno minionej „genialnej epoce”.

Chociaż przyjęło się łączyć jego narodziny jako pisarza z listami do Debory Vogel, to Schulz lokował ten moment dużo wcześniej, jeśli dać wiarę fabularyzowanemu wspomnieniu jego dawnego ucznia, później poety i prozaika - Andrzeja Chciuka.

Schulz miał mu wyznać podczas jednego ze spacerów (był w Drohobyczu zwyczaj odprowadzania ulubionych nauczycieli do domu), że „wiedział, że będzie pisał” od chwili, gdy w czerwcu 1911 roku przez przypadek stał się naocznym świadkiem masakry drohobyczan protestujących przeciw wyborczym nadużyciom władzy. Zginęło wówczas na ulicy ponad trzydzieści osób, a sto zostało rannych. Poraziła go „łatwość rozpętania kanalii i hieny w człowieku [...]. To był ten szok - jak miał to powiedzieć Chciukowi - bez którego nie rodzi się w nas pisarz"26.

\section{5}

Od 1931 roku Schulz oprócz Wiosny, Księgi, Genialnej epoki oraz Komety, a także niemieckiego opowiadania Die Heimkehr, prawie nic już nie na-

„złamanie pióra" pisze, nie licząc jego późniejszej publicystyki. Będzie się za to przez kilka następnych lat rozpaczliwie zmagał z niemożnością stworzenia swego opus magnum, jakim miała być powieść Mesjasz. Ten fakt jego literackiej impotencji jest wart głębszego zastanowienia. Fenomen „złamania pióra” jest wprawdzie dobrze znany i nierzadko występował nawet u rasowych pisarzy, jednak w wypadku Schulza można podejrzewać, że chodzi o coś innego.

Trzeba pogodzić się z tym, że Mesjasz nigdy nie powstał. Wiadomość o przekazaniu go jakiejś zaufanej osobie spoza getta oraz późniejsze sensacyjne informacje o pojawieniu się tej książki w różnych częściach świata to zrodzony z potrzeby wyobraźni literacki mit powielający schemat niezliczonych legend o zaginionym skarbie.

Schulz, kiedy po raz pierwszy uznał, że jednak nie napisze Mesjasza (a jednocześnie musiał jak najszybciej utwierdzić swoją pozycję jako pisarza wydaniem nowej książki), włączył fragmenty mające być jego częścią do Sanatorium pod Klepsydrą. Są to opowiadania Księga oraz Genialna epoka. Nie porzucił jednak w ten sposób planów dalszej nad nim pracy. 
Będzie chciał go napisać na nowo ${ }^{27}$. Z tych prób powstały urywki, które, jak można się domyślać, były na tyle niespójne, że nie nadawały się do druku jako zapowiedź powstającej powieści. Dlatego Schulz nigdy ich nie opublikował w którymś z czasopism, co było wówczas przyjętym zwyczajem. I to one, a nie cały Mesjasz, zaginęły w czasie wojny ${ }^{\mathbf{2 8}}$.

Wydaje się, że Schulz od samego początku nie miał szans na napisanie Mesjasza, przynajmniej w takiej postaci, w jakiej to sobie umyślił.

Złożyło się na to wiele okoliczności. Jedną z nich był narzucony mu ciężar niemożliwych do spełnienia oczekiwań. Schulz niemal zaraz po swoim wysoko ocenionym debiucie prosto z prowincjonalnego Drohobycza wszedł w środowisko znanych, cenionych, cieszących się wysoką pozycją pisarzy warszawskich. Obowiązywały tu charakterystyczne dla tej grupy zawodowej strategie projektowania kariery literackiej - coś, co wcześniej było mu zupełnie nieznane, bo sprzeczne z gruntu intymnym i kameralnym charakterem jego własnego artyzmu. Jego literaccy przyjaciele uznali go za takiego jak oni sami pisarza, popychając go na ścieżkę kariery typową dla zawodowego pisarstwa. Jedną z podstawowych jej zasad jest opinia, że debiut, choćby najbardziej udany, jest zaledwie wstępem do zakorzenienia się w środowisku literackim. O być albo nie być początkującego autora decyduje jego druga książka, która powinna być co najmniej tak dobra jak pierwsza. Schulz najwyraźniej uległ tej presji. Determinacja, by „przeskoczyć” swój debiut, obecna jest choćby w jego podaniu do Ministerstwa Wyznań Religijnych i Oświecenia o bezpłatny urlop, który umożliwiłby mu „skupienie wszystkich sił do całkowitego czynu artystycznego na jaki go stać [...]”, gdyż „znalazł się obecnie w punkcie swego rozwoju, w którym nie wolno mu poprzestać na połowicznych rezultatach"29.

Było to jednak niemożliwe. Sklepy cynamonowe są przykładem artystycznej doskonałości w ramach literackiej konwencji, w jakiej zostały napisane. Nie ma wśród nich lepszych i gorszych tekstów, z czym zawsze spotykamy się w zbiorach opowiadań nawet najlepszych pisarzy. Każde z nich można uznać za literacki majstersztyk. Schulz albo pisał arcydzieła, albo nie pisał w ogóle. Na tym polegał jeden $\mathrm{z}$ fenomenów jego pisarstwa.

I zapewne z pragnienia napisania książki lepszej od Sklepów cynamonowych wziął się nieszczęsny pomysł Schulza, aby Mesjasz był powieścią

27 Wynika to z listu do Romany Halpern z 12 lipca 1938 roku, listu od Witolda Gombrowicza z 19 lipca 1938 roku oraz listu od Artura Sandauera z tego samego dnia. Zob. B. Schulz, Księga listów.

28 Ficowski wśród zaginionych wówczas rękopisów Schulza umieszcza także niemal gotową już książkę, mającą składać się „z czterech większych opowieści”. Zob. J. Ficowski, op. cit., s. 95. Jednak oprócz szczątkowych wzmianek na temat tego dzieła w korespondencji Schulza nie został najmniejszy ślad będący dowodem jego istnienia.

29 B. Schulz, Księga listów, s. 234-235. 
- a więc gatunkiem bardziej cenionym i uważanym za dojrzalszy od kojarzonych głównie z debiutantami opowiadań.

Jednak Schulz do tej pory pisał wyłącznie opowiadania, nie licząc tekstów krytycznoliterackich. Nie bez przyczyny. Były to z reguły teksty o szczątkowej fabule, za to z rozbudowanymi partiami opisowymi, będącymi wyrafinowaną i drobiazgową analizą ukazanego w nich świata. Krótkie opowiadanie było formą literacką optymalną dla typu jego pisarstwa. Doskonale sprawdzała się w niej przypominająca splątany gąszcz, silnie zmetaforyzowana proza poetycka, którą uprawiał. Trudno sobie jednak wyobrazić, aby można było napisać takim językiem całą powieść. Racją jej istnienia jest przecież epickość ${ }^{30}$.

Praca nad Mesjaszem musiała więc przypominać zmaganie się z problemem kwadratury koła - była z góry skazana na artystyczną klęskę.

Schulz musiał zdać sobie w pewnym momencie sprawę, że Mesjasza nie da się napisać językiem, którym posługiwał się do tej pory. Być może dlatego Ksiega i Genialna epoka, które miały być fragmentami tej powieści, a jednak stylistycznie niczym się nie różniły od opowiadań ze Sklepów cynamonowych, zostały włączone do Sanatorium pod Klepsydra.

Postanowił więc zmienić dotychczasowy styl pisania. Wyraźnie wskazuje na to komentarz Gombrowicza odnoszący się do tego, co Schulz napisał mu o Mesjaszu w poprzednim (zaginionym niestety) liście: „Co do Twego Mesjasza to trudno mi coś powiedzieć [...] - jeśli daje Ci on możliwość odświeżenia się, to tym lepiej! Ten postulat jest ważny nie ze względu na Twoją sztukę, ale na Ciebie samego - pod względem psychicznym"31.

Wcześniej do zasadniczej odnowy pisarstwa namawiał go Witkiewicz: „[Witkacy] radzi mi zmienić zupełnie tematykę «celem naciągnięcia jajowodów, aby dokonać ostatecznego spermotrysku»"32 - relacjonował Schulz jego opinię w liście do Romany Halpern.

Jak widać, on także oczekiwał od Schulza dzieła życia będącego dokonaniem wybitniejszym niż Sklepy cynamonowe. Wyrażał jednocześnie przekonanie, że nie da się tego zrobić, pisząc jak dotychczas. W oczach tego radykalnego awangardzisty Sanatorium pod Klepsydrą, będące właściwie powtórką poprzedniej książki, musiało być jej autoplagiatem, a więc objawem twórczej stagnacji33. Mówiąc na marginesie, Witkiewicz

30 Przykładem literackiej porażki na tym polu jest choćby eksperymentalna powieść Adama Ciompy Duże litery z 1933 roku czy wyraźnie objętościowo przerośnięta Dukla Andrzeja Stasiuka. Nie jest jednak pewne, co właściwie Schulz miał na myśli, nazywając Mesjasza powieścią. W quasi-liście do Witkacego Sklepy cynamonowe nazywa "powieścią autobiograficzną".

31 B. Schulz, Księga listów, s. 248.

32 Ibidem, s. 157.

33 Po wydaniu Sanatorium Witkiewicz nie okaże tej książce podobnego jak Sklepom entuzjazmu. W liście do Schulza całą reakcją na jego lekturę Sanatorium są te kurtuazyjne słowa: „niektóre kartki wspaniałe!". Zob. B. Schulz, Księga listów, s. 289. 
generalnie był dobrym przykładem na to, jak w niewielkim stopniu rozumiano fenomen artyzmu Schulza - jego organicznego związku z językiem, jakim się posługiwał w prozie. Kilka miesięcy po publikacji Sanatorium pod Klepsydra autor Mątwy namawiał go do rzeczy dla siebie całkowicie naturalnej, ale dla Schulza całkowicie niemożliwej - by napisał „bardzo dziwną sztukę teatralną”, będącą „syntezą sceniczną cynamonów", obiecując jej wystawienie w zakopiańskim teatrze ${ }^{34}$. Sztuka ta oczywiście nigdy nie powstała.

Schulz sam musiał czuć się więźniem własnego stylu i najwyraźniej pragnął uproszczenia go, skoro w liście do Romany Halpern skarżył się, że nie został dziennikarzem, gdyż pisząc na co dzień do prasy, wyrobiłby sobie „pewną zdawkową, codzienną formę pisania”35.

Szkopuł w tym, że w zasadzie potrafił on pisać tylko w jeden, niezwykle charakterystyczny dla siebie sposób. Gdy większość rasowych pisarzy z dużą swobodą operuje w rozmaitych rejestrach języka, Schulz poruszał się niemal wyłącznie po bardzo wąskim gzymsie wypracowanego przez siebie stylu ${ }^{36}$. Dlatego nawet jego okazjonalny czytelnik bezbłędnie rozpozna każde napisane przez Schulza zdanie, tak jak czytelnik Leśmiana rozpozna każdy wers jego autorstwa.

Gdybym miał wśród pisarzy wskazać kogoś, kto był najdalszym przeciwieństwem językowego „usztywnienia” Schulza, to byłby nim Italo Calvino. Ten stylistyczny wirtuoz niemal każdą swą książkę napisał w zupełnie innej manierze i gdyby nie jego nazwisko na okładkach, nikt by się nie domyślił, że ich autorem jest ten sam człowiek.

Przypomnijmy w tym miejscu, że w przekonaniu Schulza celem sztuki nie jest mimesis widzialnego świata, ale wyrażenie najgłębszych i unikatowych treści duchowości artysty, które zostały mu dane u zarania jego istnienia ${ }^{37}$. Jedyny w swoim rodzaju język, którym Schulz wypowiadał te treści, musiał być organicznie związany z jego najgłębszym „ja”, był tego „ja” najpełniejszą, najbardziej precyzyjną ekspresją. Można nawet powiedzieć, że ten język był samym Schulzem, a Schulz był swoim językiem $^{38}$. Jego zmiana byłaby niczym zmiana skóry albo, posługując się

34 Ibidem.

35 Ibidem, s. 172.

36 To „niemal” dotyczy zamawianych u niego przez „Wiadomości Literackie” recenzji. Tutaj jego język jest bardziej „rzeczowy” i mocno uproszczony. Natomiast już w rozbudowanych szkicach krytycznoliterackich dotyczących książek, które go zafascynowały (Cudzoziemka, Ferdydurke, Granica), albo w esejach (Powstają legendy) Schulz posługuje się stylem bardzo zbliżonym do swojej prozy.

37 B. Schulz, Księga listów, s. 106.

38 Podobną rzecz Schulz napisał o podziwianym przez siebie Lilienie: „od razu znalazł swój styl, który był tak bardzo adekwatnym wyrazem jego wnętrza, tak z nim zrośniętym, że nie czuł nigdy potrzeby szukać innych sposobów; jego świat wewnętrzny skrystalizowany był i zamknięty jak u mało kogo". B. Schulz, Szkice krytyczne, s. 140. 
innym potocznym zwrotem, wejściem w cudzą skórę, więc czymś dla Schulza po prostu niemożliwym.

Pociągło to za sobą istotne konsekwencje dla pisarstwa autora Wiosny - takim językiem można było działać w zawężonym zakresie gatunkowym i na ograniczonym polu tematycznym.

\section{6}

pisanie o niemocy

Jeśli przyjrzeć się bliżej korespondencji Schulza, to okazuje się, że kłopoty z pisaniem zaczęły się wkrótce po publikacji Sklepów cynamonowych, a więc od grudnia 1933 roku $^{39}$. Będą one stale powracającym wątkiem jego listów. Pisarska niemoc, jaka na niego wówczas spadła, stanie się powodem wciąż powracających skarg, utyskiwań i samooskarżeńn ${ }^{40}$. $\mathrm{W}$ istotny sposób przyczyni się do narastania frustracji, która w pewnym momencie przeobrazi się w ciężką, dezorganizującą mu życie, wymagającą leczenia, kliniczną depresję. Znamienne, że blokada ta w dużo mniejszym stopniu dotknęła malarstwa ${ }^{\mathbf{4 1}}$.

Po raz pierwszy Schulz zwierzy się z tego trwającego już od dłuższego czasu niepokojącego go stanu Zenonowi Waśniewskiemu w kwietniu 1934 roku: „Muszę być chyba chory nerwowo. [...] nie piszę nic, nawet przepisanie czegoś napisanego sprawia mi wstręt nieprzezwyciężony"42.

Dwa miesiące później nic się w tej sprawie nie zmienia: „pogrążony jestem w głębokim upadku ducha i że zdaje się, że już nic więcej nie potrafię napisać! Pocieszam się i perswaduję sobie, że to neurastenia, ale już przeszło sześć miesięcy trwa ta awersja do pióra i to jednak nieco daje do myślenia"43.

Ostatnia wzmianka na ten temat pojawi się w liście do Anny Płockier z 4 października 1941 roku: „Nie robię teraz nic, kontempluję bogactwo wewnętrzne, moje lamusy i zbiory zebrane w życiu"44.

Z podobnych wyznań obecnych w jego listach, napisanych pomiędzy tymi dwoma punktami czasowymi, można by ułożyć litanię.

39 Sprawie tej poświęcił sporo miejsca Stanisław Rosiek w bardzo wnikliwym tekście dotyczącym rękopisu Drugiej jesieni Schulza. Siłą rzeczy, pisząc ten tekst, skorzystałem w wielu miejscach z tych samych fragmentów listów Schulza, a moje ustalenia częściowo pokrywają się z jego uwagami. Zob. S. Rosiek, Jak pisał Bruno Schulz? Domysły na podstawie sześciu stron rękopisu jednego opowiadania, "Schulz/Forum" 4, 2014.

40 Opartą na korespondencji Schulza dokumentację jego twórczej niemocy przedstawił także Józef Olejniczak, ale problem ten stał się pretekstem do innych niż tutaj rozważań. Zob. J. Olejniczak, Udręka tekstu - tekst udręki. Bruno Schulz - pisanie/czytanie, w: idem, Pryncypia i marginesy Schulza. Eseje, Gdańsk 2019.

41 B. Schulz, Księga listów, s. 185.

42 Ibidem, s. 67.

43 Ibidem, s. 69.

44 Ibidem, s. 211. 
Schulz wielokrotnie usiłował zrozumieć przyczyny swej twórczej impotencji. Mnożył na ten temat często sprzeczne ze sobą hipotezy. Ostatecznie jednak pozostała ona dla niego nierozwiązywalną zagadką. Najczęściej podawaną przez niego przyczyną była oczywiście znienawidzona szkoła, mająca zabierać mu cały czas i energię, które mógłby poświęcić na pisanie. Takim złudzeniem żył do najbliższych wakacji, kiedy okazywało się, że mimo sprzyjających warunków i dwóch miesięcy do pełnej dyspozycji i tak nie był w stanie niczego napisać.

Nie mógł więc sam uważać takiego tłumaczenia za wiarygodne, tym bardziej że Sklepy cynamonowe powstały, kiedy pracował jako nauczyciel w tej samej szkole, i wówczas nie było to żadną przeszkodą ${ }^{45}$.

Innym powodem niepisania miała być niemożność zaszycia się przed wciąż rozpraszającym go światem w jakimś odosobnionym miejscu. Tam tylko mógłby wydobyć z siebie „wewnętrzną ciszę” i zanurzyć się w zawsze płodnej dla jego pisania samotności. Kiedy jednak wreszcie udaje mu się znaleźć dla siebie taki azyl - jest nim Korostów koło Skolego ${ }^{46}$, jakaś wieś koło Turki ${ }^{47}$ czy Boberka koło Łomny okazuje się, że niczego to nie zmienia ${ }^{48}$. A przecież Sklepy cynamonowe powstały $\mathrm{w}$ warunkach dalekich od takiego ideału - $\mathrm{w}$ jego mieszkaniu na Floriańskiej, gdzie dzielił dwa nieduże pokoje z niezrównoważoną psychicznie siostrą, niesamodzielnym siostrzeńcem oraz kuzynką 49 .

Schulz w końcu zacznie podejrzewać, że przyczyna niepisania leży dużo głębiej, bo w nim samym. Uzna, że wraz z postępującym wiekiem wszedł w bezpłodną fazę życia, w której „coś się w nim popsuło”, stępiła się dziecięca wrażliwość, wyczerpały twórcze zasoby, rozwiały życiodajne iluzje, odsłaniając "nagi szkielet prawdy"50.

Czytanie prasy literackiej wprawiało go w tamtym okresie w irytację. $\mathrm{Z}$ zazdrością przyglądał się nieosiągalnej dla niego produktywności innych ${ }^{51}$. Porównując się z piszącymi przyjaciółmi, wpadał w przygnębienie. Być może wówczas zaczyna rozumieć, że nie jest taki, jak „prawdziwi" pisarze. Stwierdził, że różni go od nich jego fundamentalna i nieusuwalna wada - organiczna niezdolność do systematycznej pracy

45 Miał jednak wówczas mniejsze obciążenie godzinowe. Teraz do lekcji rysunków doszły zajęcia praktyczno-techniczne.

46 B. Schulz, Księga listów, s. 169.

47 Ibidem, s. 91. List do Zenona Waśniewskiego z 4 sierpnia 1937 roku: „Nie miałem pociechy z tej samotności i pozbyłem się iluzji starej i zakorzenionej we mnie, że jestem stworzony do samotności".

48 Ibidem, s. 147.

49 Ibidem, s. 139.

50 Ibidem, s. 90, 91, 92.

51 Ibidem, s. 136, 142. 
egzotyczna roślina

pisarskiej52. Nulla dies sine linea - poucza od dwóch tysiącleci adeptów tej profesji łacińska paremia.

Zdaje się, że Schulz faktycznie nie potrafił pisać w stałym, niezmiennym rytmie, co musi stać się niezbędną umiejętnością każdego, kto pragnie zostać pisarzem ${ }^{53}$. W listach do przyjaciół od pewnego czasu często powracał do tej sprawy ${ }^{54}$. Łudził się, że może gdyby swego czasu porzucił nauczycielstwo na rzecz dziennikarstwa, nauczyłby się takiej regularności ${ }^{55}$.

Co gorsza - pisanie było dla niego „bardzo ciężką robotą”56 i aby w ogóle je zainicjować, spełniona musiała być niezliczona ilość wstępnych warunków - jak wspomniany już wolny czas, samotność, obecność bliskiej osoby będącej rozumnym partnerem do rozmów, ogólne zadowolenie z życia itd. Było to $\mathrm{z}$ reguły niemożliwe, tak więc Mesjasz wciąż leżał odłogiem7.

Wszystko to daje dość czytelny obraz jego pisarskiej osobowości.

Nie był on jak większość znanych mu pisarzy „maszyną do pisania”, maszyną czasem wprawdzie zacinającą się, ale zaraz potem wznawiając literacką produkcję. Był raczej jak delikatna, egzotyczna roślina, której wzrost i funkcjonowanie zależą od wielu złożonych, subtelnych czynników. Czasem, mimo największych starań, usycha ona bez uchwytnych dla nas powodów.

\section{7}

To właśnie dlatego Schulz nigdy nie stał się literatem, a więc kimś, dla kogo pisanie staje się zawodem, choć po publikacji Sklepów cynamonowych bardzo tego pragnął.

Literat to zawodowy pisarz, osoba, która żyje z pisania. To profesjonalista, który ćwiczoną umiejętność sprawnego posługiwania się słowem traktuje jako posłuszne narzędzie, którego może użyć do dowolnych celów. Pozwala mu to na swobodne pisanie tekstów czysto użytkowych, takich choćby jak recenzje, felietony, reportaże, a często też teksty kabaretowych piosenek, tłumaczenia czy materiały reklamowe. Modelowymi przykładami takich pisarzy-literatów byli w dwudziestoleciu międzywojennym Julian Tuwim i Tadeusz Boy-Żeleński. Ten ostatni znany był ze swojej pisarskiej płodności obejmującej bardzo różnorodne dziedziny.

52 Ibidem, s. 182-183.

53 Możemy wskazać niezliczoną ilość świadectw mówiących o regularności pracy wybitnych pisarzy, pracy odbywającej się codziennie i w ściśle wyznaczonych godzinach. Przywołam tu choćby przykład Gombrowicza, Miłosza, Singera czy Hemingwaya.

54 B. Schulz, Księga listów, s. 123, 143, 145, 182.

55 Ibidem, s. 172.

56 Ibidem, s. 149.

57 Ibidem, s. 90. 
Na jednej z publikowanych $\mathrm{w}$ ówczesnej prasie fotografii pozuje, podtrzymując wyciągniętą do góry dłonią dużo wyższą od siebie kolumnę ułożoną ze swych książek.

Pisarze z reguły są tak rozumianymi literatami albo, gdy zajdzie taka konieczność, potrafią się nimi stać.

Skrajnie elitarny typ pisarstwa Schulza, w połączeniu z jego niewielką produktywnością, nie dawał mu żadnych szans, by żyć z pisania, mimo znacznego rozgłosu, jaki zyskał zaraz po swoim debiucie. Publikacja Sklepów cynamonowych została przecież sfinansowana przez jego świetnie zarabiającego w przemyśle naftowym brata - Izydora. Niewielkie honoraria ze sprzedanych egzemplarzy tej i następnej książki nie mogły mieć większego wpływu na sytuację materialną autora.

Zaraz po debiucie przed Schulzem otworzyły się łamy najlepszych czasopism literackich. Korzystał z tej możliwości w ograniczonym zakresie ${ }^{\mathbf{5 8}}$. Najbardziej regularną współpracę udało mu się nawiązać z ,Wiadomościami Literackimi", gdzie publikował recenzje wskazanych mu przez redakcję książek pisarzy zagranicznych. Mimo że dobrze wywiązywał się z tego zadania, znosił to raczej źle. Współpraca z czasopismem ustała na początku 1938 roku, co przyjął z wyraźną ulgą: „Przestałem pisać recenzje do «Wiadomości», bo mnie to nie bawi, przeciwnie kosztowało mnie to zawsze dużo przezwyciężenia"59 - zwierzał się Romanie Halpern.

Wspomniałem już o tym, że Schulz rozważał, czy nie rzucić szkoły, by pracować jako dziennikarz. Wydaje się jednak wątpliwe, czy w ogóle byłby zdolny do tego rodzaju pracy. Sam chyba zdawał sobie z tego sprawę, skoro ostatecznie nie zdecydował się na ten ryzykowny krok. Naprawdę trudno sobie wyobrazić tego neurastenicznego introwertyka biegającego od rana do wieczora po Warszawie, by każdego dnia dostarczyć do redakcji gazety artykuły na przykład o tym, że w Śródmieściu wykoleił się tramwaj albo że znów spadły ceny skupu produktów rolnych.

Ta pisarska nieelastyczność da o sobie znać także w okresie sowieckiej okupacji Lwowa. Schulz okaże się wówczas niezdolny do pisania według doktryny obowiązującej pisarzy w Związku Radzieckim. Jego opowiadanie o synku szewca, wysłane do „Nowych Widnokręgów”, którego tematykę najwyraźniej usiłował zbliżyć do oczekiwań marksistowskich redaktorów pisma, pod względem formalnym okazało się nie do przyjęcia ${ }^{60}$.

Rzemieślniczą sprawność oraz wydajność profesjonalisty osiągnął natomiast jako malarz. To właśnie ta umiejętność pozwalała przetrwać mu oraz rodzinie, którą się opiekował, w okolicznościach dających

58 Ibidem, s. 69.

59 List do Romany Halpern z połowy lutego 1938 roku, w: B. Schulz, Księga listów, s. 165.

60 J. Ficowski, op. cit., s. 95-96. 
znikome szanse na przetrwanie. Dla „Komsomolskiej Prawdy” wykonał wiele propagandowych ilustracji z okazji świąt komunistycznego państwa $^{61}$. Namalowane przez niego wielkoformatowe portrety partyjnych dygnitarzy wisiały na ulicach Drohobycza.

Tak więc jako grafik okazał się nieporównanie bardziej wszechstronny i elastyczny niż jako pisarz. Wykonując zlecenia dla totalitarnej władzy, potrafił niemal całkowicie unicestwić swój tak charakterystyczny styl rysowania. Kiedy przyglądamy się jego socrealistycznym rysunkom, naprawdę trudno na podstawie samej tylko kreski zdobyć pewność, że ich autorem był twórca Xięgi bałwochwalczej.

Po inwazji Hitlera, dzięki malarskim umiejętnościom Schulza, chętnie wykorzystywanym i bardzo cenionym przez stacjonujących w Drohobyczu nazistów, udało mu się uzyskać status „potrzebnego Żyda”, który chronił go przed wywózką do obozu zagłady ${ }^{62}$. Będąc „osobistym Żydem” Felixa Landaua, kupował kolejne dni życia, wykonując portrety czy dekorując pokój jego dziecka scenami z baśni braci Grimm.

O uzasadnionej, choć dwuznacznej w tej sytuacji dumie Schulza z tego powodu pisał Jerzemu Ficowskiemu Kazimierz Hoffmann - drohobycki nauczyciel i kolega autora Sanatorium pod Klepsydrą: „Brunon jak gdyby był wdzięczny swemu talentowi. Wydaje się, że pomimo zbrodniczej atmosfery, w której wówczas tworzył [...], jego projekty były chyba arcydziełami. Brunon zawdzięczał im życie. Tworzył, cieszył się, że są z niego zadowoleni. SS-mani rozkoszowali się sztuką. Brunon chodził jak w transie"63.

19 listopada 1942 roku, na rogu ulic Czackiego i Mickiewicza w Drohobyczu, gestapowiec Karl Günther strzelał do malarza, nie do autora opowiadań.

\section{8}

Inaczej niż w przypadku typowych pisarzy, Schulz nie uważał literatury za najważniejszą ze sztuk. O sobie samym tak pisał w podaniu do lwowskiego kuratorium: „Jestem malarzem z wykształcenia i powołania, jak to się czasem zdarza w ewolucji artystycznej plastyków, skierowany zostałem od pewnego czasu przez impuls wewnętrzny i potrzebę wyrazu na drogę prób i eksperymentów literackich"64. Było to dwa lata po wydaniu Sklepów cynamonowych.

61 Ł. Chomycz, Bruno Schulz podczas sowieckiejokupacji Drohobycza, "Schulz/Forum” 10, 2017.

62 J. Ficowski, op. cit., s. 98.

63 Cyt. za: J. Kandziora, op. cit., s. 225.

64 B. Schulz, Księga listów, s. 236. 
Ale to dzięki literaturze osiągnął artystyczną pełnię. W swych pracach plastycznych, choć poświęcił im nieporównanie więcej czasu i uwagi niż literaturze, nigdy nawet nie zbliżył się do wielkości, którą emanuje każdy akapit jego prozy.

W ciągu swego pięćdziesięcioletniego życia wykonał tysiące rysunków i ta znacząca liczba stanowi uderzający kontrast wobec trochę więcej niż trzydziestki opublikowanych opowiadań. Jego rozwój jako artysty plastyka (warto przypomnieć, że w zasadzie samouka) dość szybko osiągnął swój szczyt, po czym nastąpiły lata, które można określić czasem stagnacji, a nawet regresu. Daje do myślenia fakt, że największym graficznym osiągnieciem Schulza pozostała stworzona jeszcze na samym początku lat dwudziestych Xiega bałwochwalcza.

Powiedzmy to otwarcie - nie był wybitnym malarzem. Świat jego obrazów jest płaski i monotonny, nie tylko gdy porównamy go z jego światem literackim. Przy dłuższym kontakcie zaczyna nużyć jego tematyczna ciasnota, będąca konsekwencją fiksacji na jednym w zasadzie motywie - dominacji cieleśnie wspaniałych kobiet i fizycznej pokraczności korzących się przed nimi mężczyzn.

W tych grafikach o wiele konsekwentniej niż w literaturze realizuje wyrażone w liście do Stanisława Ignacego Witkiewicza przekonanie, że artysta przez całe życie krąży wokół danych mu u jego zarania kilku fundamentalnych obrazów, które tworzą jego „kapitał ducha”. Jednak w przeciwieństwie do prozy, Schulzowi nie udało się ich „przełamać [...] w całej treści, którą zdobywamy, przeprowadzić przez całą rozpiętość intelektu"65. Jego prace plastyczne są więc poznawczo mało odkrywcze, pozostają monochromatyczne nie tylko w graficznym sensie tego słowa.

Pisarstwo Schulza jest olśniewającym wyczynem jego współdziałającej z intelektem wyobraźni, która syntetyzuje z prostych pierwiastków naszej rzeczywistości wcześniej nieistniejące „Związki chemiczne”, czyniąc w ten sposób nasz świat o nie bogatszym. Stwarzała więc coś, co nie powstało w akcie boskiej kreacji świata, ale bezwzględnie powinno powstać.

Niczego podobnego nie da się powiedzieć o jego grafikach. Są one pod tym względem zwyczajnie bezpłodne, a jednocześnie pozostają wtórne wobec słynnych cykli graficznych Goi.

Przeciętność prac plastycznych Schulza, gdy chodzi o obecność w nich stwarzającej wyobraźni, staje się szczególnie widoczna, gdy zestawimy je z rysunkami często z nim porównywanego Alfreda Kubina ${ }^{66}$. Kubinowi

65 Ibidem, s. 106.

66 K. Lipowski, Demiurg jest dwoistością. Alfred Kubin i Bruno Schulz - próba porównania, „Schulz/Forum" 2, 2013. 
w grafice udało się to, co staje się największym osiągnięciem Schulza w prozie - stworzył nieistniejącą wcześniej rzeczywistość, której plastyczna sugestywność nie pozwala o sobie zapomnieć.

To nie przypadek, że Schulz za życia nie zyskał istotnego rozgłosu jako malarz, choć konsekwentnie o to zabiegał. Mimo że jego sukcesy na tym polu bywały niepozbawione znaczenia (około dziesięciu wystaw, często gdzieś na prowincji, oraz zbiorowe wystawy we Lwowie, w Wilnie i Warszawie ${ }^{67}$ ), to jednak nie uczyniły go one liczącym się w kraju artystą. Bardzo znamienne było pod tym względem fiasko jego wyprawy do Paryża, gdzie przyjechał w sierpniu 1938 roku, zabrawszy ze sobą około stu rysunków z nadzieją na ich wystawienie. Mimo kontaktów wyrobionych mu przez przyjaciół oraz obecności na miejscu życzliwych ludzi, ostatecznie nic z tego nie wyszło. Tylko częściowo można to było zrzucić na karb szczytu urlopowego w tym mieście.

Tak więc również malarskie dokonania, podobnie jak literackie, były dotknięte w jego odczuciu skazą nieurzeczywistnienia. W jednej z chwil całkowitej utraty wiary w sens tego, czym się przez całe życie zajmował, pisał do Romany Halpern: „Upadłem zupełnie na duchu. Powiedziałem sobie, że nie jestem ani malarzem, ani pisarzem, ani nawet porządnym nauczycielem. Wydaje mi się, że oszukałem świat jakąś błyskotliwością, że nic we mnie nie ma"68.

\section{9}

Jeśli nawet uznać, że nie udało mu się zostać ani malarzem, ani pisarzem, ani nawet nauczycielem (przynajmniej w takim wymiarze, jakiego sam pragną), to na pewno jedno można o nim powiedzieć bez chwili zawaKröger hania - był artystą par excellence. Był artystą zupełnie niezależnie od tego, co napisał i namalował. Artyzm stanowił sam rdzeń jego egzystencji, artyzm tak z nim tożsamy, jak to tylko możliwe. Tego rodzaju artystą nie można się stać. Nim się jest albo nie.

O takim właśnie artyzmie, który jest „tak głęboki, tak związany z początkiem i losem człowieka, że nie ma dla niego słodszego i godniejszego odczuwania nad tęsknotę ku rozkoszom zwyczajności"69, opowiada nowela Tomasza Manna Tonio Kröger. Jej bohaterem jest pisarz naznaczony od najwcześniejszego dzieciństwa piętnem artystycznego powołania. Czyni to jego egzystencję niepodobną do żadnej innej, boleśnie wyłączając go ze wspólnoty tak zwanych normalnych ludzi. Dla świata jest

67 Zob. na ten temat: U. Makowska, Dziwna awersja. O wystawach Schulza, „Schulz/Forum” 13, 2019.

68 B. Schulz, Księga listów, s. 140-141.

69 T. Mann, Tonio Kröger i inne opowiadania, tłum. L. Staff, Warszawa 1987, s. 72. 
dziwolągiem, zatopionym, niczym owad w bursztynie, w obcych przeciętnemu człowiekowi sprawach sztuki. Ale Tonio, żyjąc na co dzień wyłącznie sztuką, jest jednocześnie złakniony kontaktu z banalnym życiem i swoje odcięcie od niego uważa za rodzaj kalectwa. Tymczasem krąg jego przyjaciół zamyka się w takich samych jak on „demonach, koboldach, ciężkich potworach" 70 .

To chyba nie zbieg okoliczności, że Schulz, pisząc Romanie Halpern o swym zamknięciu we własnym świecie, z którego wydobyła go dopiero Józefina Szelińska, niemal dokładnie powtarzał autodiagnozę wypowiedzianą przez Tonia Krögera, używając przy tym charakterystycznego słowa, na które warto zwrócić uwagę: „Ona, moja narzeczona stanowi mój udział w życiu, za jej pośrednictwem jestem człowiekiem, a nie tylko lemurem i koboldem. Ona mnie odkupiła swoją miłością zatraconego już prawie i przepadłego na rzecz nieludzkich krain, jałowych Hadesów fantazji"71.

Schulz był, jak już tu wspomniałem, wielbicielem pisarstwa Tomasza Manna i trudno podejrzewać, aby nie czytał jednego z najbardziej znanych jego opowiadań, w którym na dodatek mógł znaleźć portret swego artystycznego sobowtóra.

Kobold (czyli groteskowy gnom z germańskiej mitologii) to określenie jego outsiderstwa, które zapewne należało do wspólnego szyfru Schulza i Szelińskiej, skoro tak właśnie go nazwała w liście do Ficowskiego ${ }^{72}$. Był według niej koboldem, gdyż: „nic co ludzkie nie było [mu] bliskie [...] jedyną realnością była dla niego sfera jego twórczości, [...] artysta pochłonął w nim człowieka [...], nie było w nim owego hiatus między człowiekiem a artystą [...]"73.

Trzeba tu wspomnieć o jeszcze jednej, zupełnie niezwykłej zbieżności między Schulzem a bohaterem opowiadania Manna w kontekście „kryminalnej" przygody Tonia.

Kröger po wielu latach nieobecności w swym rodzinnym mieście (jest nim oczywiście Lubeka) zatrzymuje się w jednym z jego hoteli podczas podróży do Danii. Zachodzi tu bardzo symptomatyczny incydent miejscowy policjant bierze go za poszukiwanego listem gończym oszusta. Dość przykre przesłuchanie w końcu wyjaśnia sprawę, ale Tonio wcale nie dziwi się, że został wzięty za przestępcę przez czujnego funkcjonariusza. W przekonaniu Tonia artysta jest podobnym wyrzutkiem społecznym jak kryminalista, a jego „sumienie mieszczańskie każe [...]

70 Ibidem, s. 49.

71 B. Schulz, Księga listów, s. 124.

72 Cyt. za: idem, Szkice krytyczne, s. 194.

73 lbidem. 
widzieć we wszelkim artyzmie [...] coś głęboko dwuznacznego, podejrzanego, wątpliwego [...]"74.

Kiedy przyjaciółka Schulza Regina Silberner przyleciała z mężem w 1942 roku z Hawany do Miami, FBI przesłuchiwało ich przez kilka godzin. Cały ich spory bagaż został poddany szczegółowej rewizji. Spośród licznych znajdujących się w albumach fotografii podejrzliwość wzbudziła tylko jedna - Brunona Schulza. Funkcjonariusze FBI z jakąś niepojętą natarczywością żądali szczegółowych wyjaśnień, jak się nazywa człowiek na niej się znajdujący, kim jest i gdzie obecnie przebywa. Trwało to naprawdę długo. Wreszcie pozwolono im wjechać do USA, ale wszystkie ich papiery zostały zatrzymane do dalszego zbadania. Kiedy po jakimś czasie do nich wreszcie wróciły, brakowało tylko jednej rzeczy - zdjęcia Brunona Schulza. Zapewne do dziś znajduje się ono w policyjnych archiwach pośród fotografii osobników stanowiących zagrożenie dla bezpieczeństwa państwa ${ }^{75}$.

Szelińska pisała, że życie Schulza było całkowicie podporządkowane sztuce, ale właściwiej byłoby powiedzieć o nim podobną rzecz, jaka została już tutaj powiedziana odnośnie do jego języka - ono było sztuką. Jego oddanie się sztuce powinniśmy więc rozumieć szerzej niż tylko jako całkowite poświęcenie się czynności pisania czy malowania. Czystą sztuką był jedyny w swoim rodzaju sposób codziennego istnienia Schulza, a także to, co stanowiło treść pełnego bogactwa życia wewnętrznego, będącego jego życiem właściwym. Pisanie czy malowanie stanowiło zaledwie ich materialny i fragmentaryczny przejaw.

To nie z powodu zetknięcia się z opowiadaniami czy rysunkami Schulza, ale z samym Schulzem, Debora Vogel mogła wyznać mu w liście, że „przecież rozmowy nasze dawne i kontakt nasz był jedną z tych nielicznych cudnych rzeczy, jakie zdarzają się raz jeden w życiu, a może nawet raz na kilka czy kilkanaście beznadziejnych, bezkolorowych życ'"76, a Józefina Szelińska powtórzyć to samo innymi słowami: „Te seanse u mnie $[\ldots]$ - a następnie nasze spacery na łąki $[. .$.$] dały mi przedsmak$ cudowności, niepowtarzalnych przeżyć, które tak rzadko w życiu się trafiają. Był to sam ekstrakt poezji. [...] dla Brunona młody lasek brzozowy, sama nieporadność wzruszająca, służył jako temat do snucia refleksji i gromadzenia obrazów, aby dojść niejako do głębi zjawiska"77.

Aby być dla tych kobiet poetą, nie musiał napisać nawet jednej linijki. 